\title{
Wildlife conservation through Corporate Social Responsibility initiatives in India
}

\author{
Anju Baroth* and V. B. Mathur \\ Wildlife Institute of India, Chandrabani, Dehradun 248 001, India
}

In India, the concept of corporate social responsibility (CSR) has always been embedded in the tradition of philanthropy and has focused on education, health and religious activities. Through the introduction of Companies Act 2013, these efforts are being institutionalized through a framework for taking up defined activities and spending limit. With 869 protected areas covering $165,088.36 \mathrm{sq} . \mathrm{km} \quad(5.02 \%$ of the total geographic area), India is one of the mega-biodiverse countries in the world, and requires substantial capital and efforts to conserve and manage the wide array of wildlife it holds. This study has employed secondary data analysis to highlight the activities adopted by the corporates towards wildlife conservation. It is observed that only a handful of companies are committed to supporting wildlife under CSR. Given the relatively large ecological footprint of companies, it becomes more binding on them to contribute with a modest investment to overall prospects of biodiversity conservation that can bring substantial economic and reputational benefits to them, and at the same time bring the much needed support and funds for the conservation cause. The Act provides an excellent framework for engaging the corporates in identifying the conservation needs and fulfilling their responsibility towards nature.

Keywords: Corporate social responsibility, corporates, protected areas, wildlife conservation.

THE concept of corporate social responsibility (CSR) goes a long way in Indian history and dates back to the 19th century, when it was closely connected to a politicoeconomic model. The chronology of CSR activities in India can be timed across four eras ${ }^{1}$. During the initial phase (1850-1914) CSR activities were mostly considered as a philanthropic initiative, which included donations for social and religious causes. In the second phase (1914-1960), the concept of trusteeship evolved which largely focused on strengthening social development. Between 1960 and 1980, which is considered as phase three, the model of 'mixed economy' emerged. During this phase, the business activities were controlled through legal procedures as well as through public-sector under-

*For correspondence. (e-mail: anju.baroth@wii.gov.in)

takings. The CSR activities during this phase were also pushed through these routes only. The fourth or current phase since 1980 is characterized by a mix of traditional philanthropic activities and CSR initiatives being woven into a sustainable business strategy.

The enactment of Companies Act, 2013 (Clause 135) formally mandated CSR to the checklist of Indian companies. According to Clause 135 of the Act, any company with an annual turnover of 151 million USD and more, or a net worth of 75 million USD and more, or a net profit of 0.7 million USD and more, has to comply with the provisions of the Act. It requires that such companies spend at least $2 \%$ of their average net profit from the previous three years on CSR activities. Accordingly, at present, about 6000 companies fall under the category to take up CSR projects on a mandatory basis, with many companies undertaking these initiatives for the first time ${ }^{2}$. According to a report from Pricewater Coopers (PWC), in terms of monetary commitment, Indian companies currently have CSR obligations amounting to around 3020 million USD $^{3}$. This amalgamation of regulatory and social obligation has put pressure on companies to pursue CSR activities more professionally. Box 1 shows the activities which can be taken up for CSR under the Companies Act, 2013, Clause 135-Schedule VII.

Protection of wildlife comes under item 6 in Box 1, where companies can take up activities for ensuring environmental sustainability, ecological balance, protection of flora and fauna, animal welfare, agroforestry, conservation of natural resources, and maintaining the quality of soil, air and water.

As of May 2019, India has 869 protected areas covering $165,088.36 \mathrm{sq}$. $\mathrm{km}$, which is $5.02 \%$ of the total geographic area of the country ${ }^{4}$. Such a large landscape requires sustained efforts and substantial funds to conserve, manage, restore, recover and monitor wildlife, its population and the habitat. There is too much emphasis on conservation only but seldom on protection, with long-term studies using scientific approaches. This calls for a change in the conservation approach in India, wherein the corporate agencies should initiate collaboration with scientific institutions for developing robust and result-driven conservation plans. Some business groups realize that biodiversity and development are closely linked, and that the pressure of developmental activities on biodiversity is not always positive. Mandate to 
Box 1. List of activities included under Companies Act, 2013

1. Eradicating extreme hunger and poverty

2. Promotion of education

3. Promoting gender equality and empowering women

4. Reducing child mortality and improving maternal health

5. Combating human immunodeficiency virus, acquired immunodeficiency syndrome, malaria and other diseases

6. Ensuring environmental sustainability

7. Employment enhancing vocational skills

8. Social business projects

9. Contribution to the Prime Minister's National Relief Fund or any other fund set-up by the Central Government or the State Governments for socio-economic development, and relief and funds for the welfare of the Scheduled Castes, Scheduled Tribes, other backward classes, minorities and women

10. Such other matters as may be prescribed

conserve biodiversity under CSR can go far in reversing the present loss of biodiversity and degradation of the ecosystem and its services. The partnerships with business groups under the CSR Act to conserve biodiversity, and using their experience to design enhanced policies and programmes can lead to better management of resources, nature and ecosystem services. Such opportunities can also bring reputational benefits to the corporates since 'planet versus development' has become the buzzword at present. On the other hand, such efforts can significantly expand the conservation outlook that often gets compromised due to fund limitations. This article reviews the various interventions being taken up by the Indian industry in wildlife conservation.

\section{Tata group}

Tata group is one of the largest business groups in India with 29 publicly listed enterprises and a market share of about 134 billion USD (as on 31 March 2015). The Group supports education, health, livelihood generation, and art and culture through philanthropic trusts which hold $66 \%$ of its equity share capital ${ }^{5}$. In the domain of wildlife conservation, four entities of Tata Group, viz. Tata Chemicals Ltd, Tata Steel Ltd, Tata Housing Development Company Ltd and Tata Consultancy Services Ltd are primarily working to protect threatened species in India under the umbrella of CSR.

\section{Tata Chemicals Limited and Save the Asian Lion Project}

The role of Tata Chemicals in the protection of whale shark can be considered as one of the best examples in the industry for the conservation of a species, which was under threat due to heavy poaching and was declining rapidly. The species is currently listed under Schedule I of the Indian Wildlife Protection Act (1972) and is Endangered according to the IUCN Red List.
The whale shark is the largest fish species in the world, which is poached for meat and oil. The Gujarat coast was recorded to be the fishing and slaughtering grounds of these huge fishes. To protect this rare and endangered fish species, the 'Save the Whale shark Initiative (SWI)' was taken up by Tata Chemicals in 2004, in partnership with the Wildlife Trust of India and Gujarat State Forest Department. This programme was not only designed to study the behaviour and migratory pattern of whale shark, but also to create awareness regarding the need for conservation of the species. The campaign emphasized more on creating awareness amongst the coastal communities in Saurashtra region. Further, in order to gain support from fishermen and the locals, a spiritual leader (Morari Bapu) was chosen as the brand ambassador for the campaign. The campaign resulted in changing the perception of this giant fish as just a source of meat, flesh and oil, to the 'daughter of Gujarat' which returns home from her in-laws to give birth to little ones. The campaign ended with a relief programme that provided financial support to fishermen whose fishing equipment such as nets were damaged during the rescue mission. The campaign gave rise to a positive change in the coastal regions of Saurashtra. Today, if whale sharks are caught by the fishermen, they free them instead of using them to make money. Such was the success of the conservation initiative. As of July 2015, 498 whale sharks were rescued and willingly released by fishermen back into the sea.

In the next phase of this programme, four whale sharks were tagged for the first time in India with marker and satellite tags, to understand their migration and monitor the success of SWI. The unique feature of this programme was the involvement of 132 fishermen who were trained to deploy marker tags on the rescued fishes. The programme also involved scientific studies on the ecological and genetic components of whale sharks.

Another conservation project of Tata Chemicals is 'Save the Asian Lion Project' in Gir, Gujarat. The Gir National Park is the last fortress of the endangered 
Asiatic lion. One of the threats to these 400-plus lions are open wells inside the National Park due to which several of them have been killed in the past. In this context, in partnership with the State Forest Department in Gujarat, Tata Chemicals launched a project in 2008 to save this species. Through this project, parapet walls were built around open wells which made them safe for lions and other wildlife. This helped in reducing the mortality risk to Asiatic lions and other species due to falling in open wells. To date, some 1204 open wells have been upgraded at the cost of 126,840 USD, which is contributed by the Tata Group.

\section{Tata steel and Tata Consultancy Services - Turtle Conservation Programme}

A subsidiary of the Tata Group, Tata Steel Limited is into mining and steel manufacturing. The company in association with Larson \& Toubro Ltd is developing one of the biggest deep-sea ports, Dhamra Port on River Dharma. The site is located about $15 \mathrm{~km}$ north of Gahirmatha in the Odisha and is recognized as a mass nesting site of Olive Ridley turtles. Environmental groups have expressed concern that the port will severely endanger the existence and nesting of these turtles. Tata Steel in association with International Union Conservation National (IUCN) undertook a study to assess the impact of the project on these turtles and the overall environment. The study identified impacts on turtle hatchings from artificial lighting; dredging and secondary industrial and urban growth. Based on the IUCN recommendations, special port lights were installed which ensured minimum light scattering in the sky so that it does not impact or disorient the turtles. This has served as an example of turtlefriendly lighting in India ${ }^{6}$.

IUCN also recognized that the most serious threat to the turtle population in the area was trawler fishing, which often inadvertently traps and kills turtles in nets. IUCN and Odisha Forest Department jointly organized a turtle excluder device (TED) workshop in November 2010 with the aim to promote sustainable fishing practices for fishermen from the villages neighbouring Dhamra Port, and also promote the use of TED in trawl fishing in order to prevent the trapping of the species in the nets ${ }^{7}$.

Another subsidiary of the Tata Group, viz. Tata Consultancy Services initiated 'The Marine Turtle Conservation Programme' along with the coastal villages of Maharashtra between 2011 and 2014. In this endeavour, 113 nests and a large breeding population of endangered (female) Olive Ridley turtles were protected. This project resulted in successful translocation of 12,119 eggs of the species to a hatchery, and a release of 6075 hatchlings into their natural habitats ${ }^{8}$.

\section{Tata housing - Endangered species conservation}

Another business of Tata Group known as Tata Housing, collaborated with WWF-India and donated 60,400 USD during 2014-2015 and thereafter committed to contribute a total of about half a million USD until 2018, for the conservation of the Great Indian bustard in Desert National Park, Rajasthan; red panda in Arunachal Pradesh, and one-horned rhinoceros in Laokhowa-Borachapori Wildlife Sanctuary, Assam.

Tata Housing is also engaged in tiger conservation across six landscapes of India, viz. Terai Arc, Sundarbans, Satpuda-Maikal, North Bank, Kaziranga Karbi Anglong and the Western Ghats. The company has helped by training the forest staff and providing them with protective gear to curb poaching of tigers in these landscapes. In addition, the frontline personnel of tiger reserves, national parks and sanctuaries were provided with patrolling equipment such as GPS, compass, binoculars, digital camera, LED torch, winter jackets, trekking shoes, backpacks, mosquito nets, raincoats, patrolling vehicles, etc.

The company is also associated with snow leopard conservation in Ladakh, which accounts for 5-10\% of about 7000 snow leopards in the world. Through a crowd funding effort with WWF-India, Tata Housing worked towards awareness creation among the public about this vulnerable species. Currently, the company is funding projects to estimate the population of snow leopards in the region.

\section{The Muthoot Group - Human-elephant conflict management programme}

The Muthoot Group is a diversified business group with a major stake in financial services. The logo of the Group displays elephants and the company has special interest in the conservation of this species. It has collaborated with WWF-India for managing Human-Elephant Conflict and protecting elephant habitats. The company has donated 75,000 USD under its CSR mandate to protect elephants across six Indian states, namely Assam, Arunachal Pradesh, West Bengal, Uttarakhand, Tamil Nadu, and the company's home state of Kerela. The project focuses on the development and training of anti depredation squads across elephant attack-prone areas in these states. Funding for low-cost solar fences in villages and electric fencing around agricultural fields is also provided. Investment is also made on the use of advanced technology like infrared motion sensors that work on the concept of detecting activity (elephant) through sensors in the nearby areas and activating the alarms in return. In addition, the villagers are equipped with torch and searchlights to help them spot elephants and thus prevent damage to crops, property and life. 


\section{Sony India Limited - Red panda and snow leopard conservation}

Sony India a subsidiary of Sony Corporation, Japan is an electronic and media giant. It is working for the conservation of red panda and snow leopard in Arunachal Pradesh. The snow leopard can be found at a height of $>3000 \mathrm{~m}$ amsl, in the Himalayan states of India and is often called 'the ghost of the mountains'. It is usually hunted for fur, bones, meat and other body parts for medicinal and other purposes. On the other hand, red panda, the state animal of Sikkim, is mostly found in Arunachal Pradesh, Sikkim and West Bengal (northern part). In addition to the threats of poaching and habitat degradation, this species faces threat from feral dogs. The project funded by Sony India and in collaboration with WWFIndia focused on estimating the population status and generating baseline data for the two species. Other objectives of the project included a study on ecology, habitat requirements and potential threats. Additionally, effective mitigation measures to prevent and manage humanwildlife conflicts have been developed and implemented.

The company also runs sustainable livelihood programmes for local communities of the region, making them self-reliant and empowering them to adopt alternate livelihoods, which has resulted in making them less dependent on forest produce and minimizing likely human-wildlife conflicts. The projects reinforced the community conserved area management committees by developing capacity, providing resources, training, and advocating for good governance policies with the respective states ${ }^{9}$.

\section{Godrej and Boyce Manufacturing Company Limited - Marine Ecology Centre}

Godrej \& Boyce Manufacturing Company Limited is a holding company under the Godrej Group. As part of the wildlife conservation initiative, the company established the Soonabai Pirojsha Godrej Marine Ecology Centre (Vikhroli, Mumbai) in 1985, to protect the 750 ha of mangroves. The main objective of the Centre is the conservation of marine diversity through research, education, raising awareness and regular monitoring. Through the conservation efforts of this company, a rare sight of flourishing biodiversity can be seen in a city like Mumbai, which is otherwise devoid of rich flora and fauna. This Centre today supports several marine faunal species of fishes (20), crabs (15), prawns (7) and molluscs. It is home to rich terrestrial fauna species, including birds (206), reptiles (33), spiders (30), mammals (12) and over 82 different species of butterflies. The Centre is continuously engaged in running research projects on ecology and restoration of mangroves, and also works on increasing awareness among the community through education.

\section{Oil and Natural Gas Corporation - Eastern Swamp Deer project}

The Oil and Natural Gas Corporation (ONGC) is the largest oil and gas exploration and production company in India. It has the credit of being one of the biggest spenders on CSR in India, contributing nearly 75.5 million USD. ONGC collaborated with the Wildlife Trust of India in 2010, for the rescue of the endangered subspecies of the eastern swamp deer. Kaziranga National Park in Assam is the last remaining habitat of about 681 surviving animals of this species in the world. Through this project, ONGC aimed for long-term conservation of this species and has donated a funding of 128,250 USD to the Assam Forest Department for this cause. The conservation strategy involved the estimation of population dynamics, threats and factors restricting the growth and distribution of the eastern swamp deer. This also included the development of new viable populations outside the Park, if required ${ }^{10}$.

In 2007, ONGC in association with the Bombay Natural History Society (BNHS) in Gujarat and Maharashtra, worked for the restoration of about 200 ha of degraded mangroves. The restoration work was carried out with the help of local communities, who were trained initially and grouped into mobile education units for conducting mangrove restoration work. In the past, over 1000 such educational activities have been initiated by teachers and students with a focus on conservation of coastal biodiversity, involving about 60,000 students and 1500 teachers. The awareness programme covered 20,000 locals of fishing community from 250 coastal villages and provided employment to 150 trained personnel in Gandhar, Gujarat ${ }^{11}$.

\section{Nokia India - River Watch Project}

Nokia India Sales Pvt Ltd, a subsidiary of Microsoft mobiles OY supports several biodiversity conservation programmes ranging from wetland to tiger and Nilgiri tahr conservation. In 2009, the company collaborated with WWF-India and the Department of Forests and Wildlife Preservation, Punjab, to initiate the 'River Watch Project $^{12}$, a programme for the biomonitoring of freshwater biodiversity in the Satluj-Beas-Ravi rivers in Punjab, which covers the Harike Wetland, a biodiversity hotspot. The purpose of the project was to record the numerous species that reside across various stretches of Punjab. The constant infrastructural encroachment and pollution are but a few of the numerous daunting challenges faced by the region, and thus proved a worthy reason for undertaking the project. Since its inception in 2010, the 'River Watch Project' has recorded 9 mammals, 200 avian species, 7 turtle species and 26 fish species in this wetland ${ }^{13}$. The project also allowed implementation 
of sustainable local policies and practices near the Harike Wetland, such as the use of biofertilizers to help reduce habitat degradation as well as pollution levels.

In 2011, the mobile company completed a Nilgiri tahr conservation programme in the southern Western Ghats. The programme was aimed at developing structures for the protection of the Nilgiri tahr (an endemic species of the region), mitigation of human-elephant conflicts, and building of community capacity for sustainable livelihood and conservation. The programme, based on multistakeholder participation and sector-based cooperation, guaranteed sustainable ecological security in the landscape. The study identified the most reliable population size for the species till date. Additionally, 17 completely new smaller populations of Nilgiri tahr were identified. A conservation alliance for the species was also established with support from local NGOs and the Wildlife Association of Rajapalayam to work towards future monitoring and conservation of the Nilgiri tahr in Rajapalayam $^{14}$.

\section{Rio Tinto India - Vulture Project}

Rio Tinto Group is an Anglo-Australian metals and mining corporation headquartered in London, UK. In India, the company went into State Support Agreement with the Government of Madhya Pradesh for a mining lease for the Bunder Diamond Project. The mining region of the project in Bundelkhand, Madhya Pradesh has a flourishing bird population and is a natural habitat for vultures. The Indian vulture, which is critically endangered since 2002, has witnessed a huge decline in its population in the recent past. Rio Tinto and BNHS have partnered since 2014 with the aim to protect the Indian vulture population by setting-up a 'vulture safe zone' of about 32,000 sq. km around Bunder Diamond Project area. The project has adopted a multipronged approach in which apart from monitoring and tracking of vulture population, awareness among local people about vulture conservation was also raised. So far, about 20,000 locals have been educated about the conservation significance and the role of vultures in the whole ecosystem. Another major initiative was to monitor the use of banned diclofenac (a veterinary drug used as a painkiller for cattles in the past) through regular carcass sampling ${ }^{15}$.

\section{Aircel - 'Save Our Tigers' project}

Aircel Ltd, a mobile service provider in India took up the 'Save Our Tigers' initiative in 2008 with an aim to raise mass awareness about the status of tigers and their conservation. The primary objective of the programme was to raise awareness amongst school children in the large cities and 'tiger towns' (smaller cities close to tiger reserves) on the plight of the tigers and the important role they play in ecological balance. In a unique drive, the project helped introduce the concept of kid's safari with Sanctuary Asia 'The Kids for Tigers Express', which is a fully equipped education and entertainment van that passes around the villages in Ranthambore National Park and promotes awareness among the communities about the need to protect the tigers.

In another initiative, Aircel partnered with the Wildlife Conservation Trust to deploy and implement high impact on-ground projects. This initiative was highly successful as it developed and deployed 41 rapid response units in 35 tiger reserves, refurbished 1167 anti-poaching camps across majority of the tiger reserves and trained a large number of frontline forest guards in various aspects of conservation $^{16}$.

\section{The Hongkong and Shanghai Banking Corporation Limited - My Ganga, My dolphin}

Hongkong and Shanghai Banking Corporation (HSBC) is a banking and financial multinational company. In October 2012, the company initiated a campaign 'My Ganga, My Dolphin' to conduct a dolphin survey. WWF was the implementation partner for this project and Uttar Pradesh Forest Department along with 18 NGOs were the associates. The Ganges river dolphin (Platanista gangetica) is endemic to the Ganga and Brahmaputra rivers in India, and is locally called as 'susu' or 'soons'. It is the topmost species in the aquatic trophic level and is often called 'tiger of the Ganges'. The presence of this species in the water system is an indication of a healthy river ecosystem. During the past few years, this species has witnessed a drastic decline in its population due to several developmental activities, specifically construction of waterways, dams and barrages on the rivers resulting in heavy siltation and lean water flow. It is estimated that the population of Gangetic dolphins has reduced from about 5000 in year 1982 to $<2000$ at present. The species is the National Aquatic Animal of India, and is currently categorized as 'Endangered' under IUCN Red List and is also covered under Schedule I protection of the Wildlife Protection Act, 1972. The 'My Ganga, My Dolphin' campaign by $\mathrm{HSBC}$, included a survey of the entire Ganga river and its tributaries (Yamuna, Son, Ken, Betwa, Ghagra and Geruwa). The survey recorded the presence of 671 dolphins. The campaign also raised awareness among local communities regarding the conservation significance of the species as well as helped in the capacity building of stakeholders associated with its conservation. The programme led to the preparation of an implementation strategy of the Dolphin Action Plan, 2010-2020, by Ministry of Environment, Forest and Climate Change, Government of India ${ }^{17}$. 


\section{Conclusion and recommendations}

It is clear that the challenges of conserving biodiversity can be best addressed by developing a symbiotic relationship between different sectors of the society, including corporates, which can play a central role in the global effort to achieve truly sustainable development. Alliances with business groups and funding through CSR for conservation can lead to success stories of biodiversity conservation, responsible decision making and better management of natural resources. A critical factor to the success of such initiatives is the collaboration with serious and genuine conservation organizations or specialized institutions which can identify the areas requiring immediate as well as long-term conservation interventions and drive the programmes to successful completion. Such institutions are required to work in close partnerships with a range of stakeholders to design, plan and implement conservation agenda in a responsible and effective manner. Such specialized institutions for partnership could be Government institutions, NGOs, conservation groups, academic institutions and universities working on wildlife, forests and biodiversity conservation. The stakeholders or funding agencies could be large corporate groups, small-medium enterprises, Maharatna and Navratna companies from the Government sector, and international partners or any such organizations, which fall under the category of the Companies Act. This symbiotic association works in two ways. First, it helps the corporates achieve their sustainability goals and second, it aids the natural resource managers with necessary funding essential for strategic planning and implementation of conservation initiatives.

It is important that the conservation programmes and campaigns are selected based on science-based researched information for different species or habitats. The data and outputs from such programmes must be shared with the policy makers in order to develop appropriate conservation policies and schemes. In addition, the information must also be widely circulated among media, fellow business groups, and the general public so that the positive impact and learnings of the success stories could be absorbed and more support for conservation could be gathered.

In addition to the conservation of wildlife, it is equally important that forests and protected areas be given similar importance and priority by these business groups. There is no denying the fact that forests, wildlife, human wellbeing, and economic growth are inextricably linked. As the impact of deforestation and forest degradation on climate change is significant, encouraging long-term research to reduce the loss of forests can have several benefits for people and ecosystems. Some areas needing immediate attention for research can include themes related to reduction of greenhouse gas emissions, carbon sequestration potential of different forests, quantification of ecosystem services of different landscapes and maintenance of undisturbed forest patches. Traditionally, corporates have been engaged in promoting 'education and health' sectors and contributing towards pollution and climate change initiatives. The 'buy-in' for forests and wildlife would require more effort and perseverance. Over time the focus is now shifting to issues related to habitat transformations, conservation, and management of threatened and endangered species.

The case studies in this article highlight the wide range of initiatives taken by the companies in India to address wildlife conservation. However, these are only a handful, given the vast expanse of protected areas and wildlife in the country that need more resources for better management and conservation.

Corporate commitment and support to conserve biodiversity and natural resources can go a long way in the reversal of damage that is being done to forests, wildlife, ecosystems and their services. Accepting the needs, issues and challenges related to critical habitats and endangered species, while at the same time willingness to support diversified themes for management and conservation can not only make the companies truly sustainable but also bring reputational and business benefits to them. It is a fact that larger business groups have a relatively higher dependence on natural capital, thus making their ecological footprint bigger. Considering this, it is even more binding for such business groups to contribute as much as possible towards the concept of resource conservation, wildlife habitat management, reforestation, restoration of degraded ecosystems, protection of endangered/ threatened/vulnerable species and overall environmental enrichment. CSR is not just an Act to comply with, it is an opportunity for the corporates to bond closely with nature and repair the damage caused as a result of their actions. The Act provides an excellent framework for engaging the corporates in identifying the conservation needs and fulfiling their responsibility towards nature. The framework is ready, 'walk the talk' is needed.

1. Sundar, P., Beyond Business: From Merchant Charity to Corporate Citizenship, Tata MacGraw-Hill, New Delhi, 2000.

2. Ministry of Corporate Affairs, Government of India (GoI), Schedule VII of the Companies Act 2013 - Ministry of Corporate Affairs, 28 February 2014; retrieved from http://www.mca.gov.in/ Ministry/pdf/CompaniesActNotification3 2014.pdf

3. Pricewater Coopers, Handbook on Corporate Social Responsibility in India, PWC-CII, Gurgaon, 2013.

4. National Wildlife Database, Protected Areas of India, 2019; retrieved from http://www.wiienvis.nic.in/Database/Protected Area 854.aspx

5. Tata Group, Tata Group Profile, 2016; retrieved from http://www.tata.com/aboutus/sub index/Leadership-with-trust

6. Tata Steel, Corporate Social Responsibility Report, Tata Steel Ltd, Jamshedpur, 2009.

7. The Indian Wildlife (Protection) Act, 1972; retrieved 21 April 2016; retrieved from http://envfor.nic.in/legis/wildlife/wildlife1.html 


\section{REVIEW ARTICLES}

8. Indian Wildlife Business Council, Case studies of interventions by industry, Confederation of Indian Industry (CII), 2014; Retrievable from https://cii.in/Publicationform.aspx?enc=tdsRsykoqK8qEP1NZCnEos7sR3Z/0RisIAAB1RDbk05i1Mc1nwpxPOxDE0HdfAio

9. World Wildlife Fund, WWF-India partners with Sony India to strengthen community based conservation programmes for the red panda and the snow leopard in western Arunachal Pradesh. WWF, 2015 .

10. Wildlife Trust of India, ONGC, WTI collaborate to assist Assam FD on eastern swamp deer conservation. WTI, 2010.

11. BNHS, Project Mangrove, Bombay Natural History Society, Mumbai, 2007.

12. WWF India. Milestones - 2009; https://d2391rlyg4hwoh. cloudfront.net/downloads/wwf annual report.pdf (retrieved on 27 June 2019).

13. Nawab, A., Kanwar, G. and Khan, S., On the water front: integrating science with policy and practice. In 14th International River Symposium, Brisbane, Australia, 26-29 September 2011; http:// archive.riversymposium.com/index.php?element=C2A+NAWAB. pdf (retrieved on 27 June 2019).
14. Predit, P. P. et al., Status and distribution of the Nilgiri Tahr Nilgiritragus hylocrius, in the Western Ghats, India. Technical Report, WWF-India, 2015; http://awsassets.wwfindia.org/downloads/status_and_distribution_of the nilgiri_tahr_in the western ghats india final.pdf (retrieved on 27 June 2019).

15. Rio Tinto, Case study: conserving India's critically endangered vultures, 6 April 2016; retrieved from http://www.riotinto.com/ ourcommitment/features-2932_16896.aspx

16. Aircel Ltd, Aircel CSR Policy, 5 April 2016; retrieved from http://www.aircel.com/AircelWar/images?url=/ucmaircel/groups/ public/documents/webas set/csr_policy_pdf.pdf

17. India Water Portal, The 'My Ganga, My Dolphin' campaign. 2012; retrieved from http://www.indiawaterportal.org/sites/ indiawaterportal.org/files/my ganga my dolphin campaign oct5to72012 wwfindia.pdf

Received 21 December 2017; revised accepted 29 April 2019

doi: $10.18520 / \mathrm{cs} / \mathrm{v} 117 / \mathrm{i} 3 / 405-411$ 